\title{
PEMBUATAN BIOGAS DARI LIMBAH TERNAK SAPI PERAH DAN PUPUK ORGANIK AMPAS BIOGAS KERING
}

\author{
Rizki Agung Novariyanto ${ }^{1)}$, Hendri Setiawan ${ }^{2)}$ \\ IKIP Budi Utomo Malang, Jl. Citandui 46, Kota Malang \\ 1) email: rizkiagungoke@yahoo.com
}

\begin{abstract}
Abstrak
Kemiri is a village in Malang located on the border of the District Malang with Pasuruan region. Most of the people are farmers lading and maintain dairy cows as their daily work. Impurities cause waste that pollute the environment in the form of odor and contaminate soil and water. Cow dung Colly contains toxins and bacteria that endanger human health and the environment. The results of the survey team IbM and analysis of problem situations faced by Partner IbM, very urgent and need help are as follows: (1) Waste cow manure Partners cause environmental pollution, (2) Lack of energy for cooking are still using firewood and LPG subsidy (3 Kg) that it is still heavy, (3) Not understanding Biogas manufacturing technology and lack of capital. (4) Expensive and scarce chemical fertilizer in the field, (5) the limitations of materials and equipment manufacture organic fertilizer. On the basis of the measures to solve the problem is (1) Holding Extension of cleanliness, making biogas and organic fertilizer packaging of the pulp biogas (bioslurry), (2) Preparation of tank biogas (digester) type Fixed Dome made of brick or concrete, and their installations and equipment up to the utilization / operations, (3) dry Organic Fertilizer Production packaging $25 \mathrm{Kg}$ of bioslurry. Thus, the target output or outcome in Service program is the biogas as a source of energy / fuel for IBM partners fund and organic fertilizer packaging 25 $K g$ as a substitute for chemical fertilizers and unnatural.
\end{abstract}

Keywords: Cow dung, biogas, organic fertilizer.

\section{PENDAHULUAN}

Kecamatan Jabung Kab. Malang adalah salah satu kecamatan di Kab. Malang penghasil susu sapi perah. Masyarakatnya di beberapa desa di kecamatan tersebut banyak yang memelihara ternak sapi perah. Dari ternak sapi dihasilkan susu sapi yang ditangani oleh koperasi susu. Rata-rata setiap ekor sapi perah menghasilkan 10 15 liter susu sapi setiap harinya, bahkan untuk usia produktif bisa menghasilkan 20 liter setiap harinya. Rata rata para peternak memelihara antara 2 hingga 10 ekor sapi, bahkan ada yang lebih dari 10 ekor sapi perah.

Di desa Kemiri Jumlah pemilik Biogas masih sedikit sekali, tidak sebanding dengan jumlah peternak sapi dan populasi ternak sapi perah yang ada di sana. Hal ini berakibat jumlah kotoran sapi yang ada melimpah ruah dan menimbulkan polusi yang mencemari lingkungan. Kotoran sapi perah mereka masih di buang sembarangan di belakang kandang dan halaman rumah mereka, mengalir kedalam selokan saluran air terbuka dan terus ke sungai. Bau yang tidak sedap dan gumpalan-gumpalan kotoran sapi berserakan di selokan dan saluran air di pinggir-pinggir jalan dan sungai yang melewati desa Kemiri.

Kebutuhan akan Biogas untuk memanfaatkan kotoran sapi sangat besar dan masyarakat sangat antusias untuk memilikinya, hanya saja persoalan yang menghambat pembuatan biogas permanen di desa ini adalah mahalnya biaya pembuatan infrastruktur biogas dan peralatannya. Masyarakat umum yang lewat di jalan-jalan sekitar pemilik ternak sapi serta warga yang tidak memelihara sapi perah juga mengeluhakan limbah kotoran sapi yang dibuang sembarangan, hanya saja mereka diam karena ketidakberdayaan mereka. 
Energi biogas adalah solusi terbaik untuk memenuhi kebutuhan energy secara mandiri. Selama ini proses pembuatan biogas dianggap tidak praktis, menjijikkan dan agak ribet, sementara harga BBM dan elpiji dianggap masih lebih murah. Sekarang hal tersebut sudah tidak berlaku, karena setiap saat Pemerintah senantiasa dipusingkan dengan kebutuhan energy yang terus meningkat, sedangkan cadangan energy dari alam semakin habis. Diperkirakan kebutuhan energi dan Pangan Indonesia pada tahun 2035 akan bertambah $40 \%$ dari saat ini karena pertumbuhan penduduk akan mencapai 305,6 juta jiwa dari 237,6 juta jiwa tahun 2010.

Disamping itu, produk ampas biogas (bioslurry) mereka dapat diolah menjadi pupuk organik secara komersial. Ampas biogas (bioslurry) tersebut dapat dimanfaatkan tidak hanya sebatas keperluan pupuk bagi mereka sendiri, tetapi ampas biogas tersebut dapat di olah menjadi pupuk organik kemasan sebagai pengganti pupuk kimia yang mahal. Pupuk kemasan tersebut dapat diperjualbelikan secara bebas sebagai produk UKM yang akan menambah penghasilan mereka.

Pemakaian pupuk Kimia dalam jangka panjang dan sembarangan bisa berakibat buruk terhadap kondisi tanah, merusak kesuburan tanah, dan merusak lingkungan. Dari tahun ke tahun data jumlah lahan pertanian yang mengalami kerusakan akibat penggunaan pupuk kimia yang berlebihan prosentasenya terus meningkat, Oleh karenanya Departemen Pertanian menghimbau penggunaan kembali pupuk organik.

\section{METODE PENELITIAN}

Pemilihan pembuatan infrastruktur biogas dan pemanfaatan bioslurry sebagai pupuk organik kemasan, didasarkan pada kondisi desa Kemiri yang masyarakatnya banyak memelihara ternak sapi perah. Melalui program IBM ini diharapkan:
A. Kebersihan lingkungan jadi terjaga, kandang menjadi bersih, binatang ternak sehat, produk susu meningkat dan harga jual ternak jadi lebih mahal.

B. Kebutuhan energi dapat terpenuhi secara mandiri, utamanya keluarga dari peternak sapi perah yang kurang mampu.

C. Kandungan Methana (CH4) akibat kotoran sapi yang dibiarkan menumpuk dan menguap di udara menimbulkan pemanasan global.

D. Bioslurry dari uji lab diketahui sangat bagus sebagai pupuk organik, murah, (Satu liter limbah cair) setara fungsinya dengan 20 gram urea yang dilarutkan dalam satu liter air. Aman dan ramah lingkungan.

E. Kelangkaan pupuk dapat teratasi, dengan pupuk organik kemasan yang murah dan ramah lingkungan.

F. Menambah pendapatan keluarga.

Dari permasalahan mitra yang telah dipaparkan di atas dan solusi yang ditawarkan seperti di atas maka metode yang dilakukan melalui pendekatan sosial personality bagi masyarakat desa. Pendekatan tersebut disesuaikan dengan karakteristik masyarakat desa yang sifatnya tertutup dan pemalu sehingga perlu pendekatan personal (door to door) agar keluarga masyarakat yang menjadi obyek penelitian ini dapat menerima sosialisasi dengan terbuka.

Untuk menentukan populasi dan sampel yang cocok dalam penelitian ini didasarkan atas kriteria ekonomi (family economics), dan kebutuhan terdesak (desperate need). Kedua pemahaman tersebut didasarkan atas semakin rendahnya pendapatan yang dimiliki satu keluarga pasti akan memberikan dampak domino pada kemampuan memenuhi kebutuhan sehari-hari. Ditambah pula dengan keinginan untuk mendapatkan atau memiliki fasilitas yang dapat membantu meringankan pemenuhan kebutuhan keluarga. 
Berdasarkan penjabaran tersebut, dapat diterapkan melalui:

A. Mengadakan Sosialisasi/ Penyuluhan tentang kebersihan lingkungan, Biogas dan manfaat Bioslurry di lingkungan desa Kemiri. dengan melibatkan dinas terkait di wilayah setempat dan Kepala Desa Kemiri Kec. Jabung Kab. Malang.

B. Pembuatan Digester (tangki prosesor biogas) volume $6 \mathrm{~m} 3$ dari batu bata dan beton beserta instalasi dan peralatannya di lokasi mitra Ibm, bekerja sama dengan tenaga ahli terlatih binaan dinas peternakan dan KUD Kan Jabung. Mitra IBM akan menyiapkan lahan, Membantu pembuatan pekerjaan biogas secara gotong-royong.

C. Pembuatan pupuk organik kering kemasan Plastik $5 \mathrm{Kg}$ beserta bahan, proses pembuatannya dan peralatannya dari bahan limbah biogas.

\section{HASIL DAN PEMBAHASAN}

\section{A. Penyuluhan Pemanfaatan Kotoran} Sapi Sebagai Bahan Biogas.

Melimpahnya kotoran sapi di Lingkungan rumah para peternak sapi perah dusun Krajan desa Kemiri, Kecamatan Jabung, Kabupaten Malang dapat dimanfaatkan menjadi energy alternative biogas. Ada banyak keuntungan dari pemanfaatan kotoran sapi menjadi biogas yaitu:

1) Lingkungan menjadi bersih, bebas dari limbah yang dapat menggangu kesehatan manusia dan lingkungan di sekitarnya.

2) Para peternak sapi perah akan memperoleh energi secara gratis tanpa perlu membeli untuk kepentingan memasak dan dapur mereka, serta bisa juga untuk lampu penerangan di malam hari.

3) Para peternak sapi perah tidak lagi memerlukan kayu bakar untuk kebutuhan memasak mereka, tidak ada lagi kekhawatiran penebangan pohon hanya untuk kayu bakar, sehingga kerusakan alam akibat penebangan liar di hutan dan kebon petani dapat dihindari.

4) Kebutuhan akan pupuk dapat terpenuhi secara mandiri berupa pupuk organik dari hasil sampingan produksi biogas. Pupuk ini kaya akan zat-zat hara yang diperlukan bagi pertumbuhan tanaman.

5) Para peternak sapi perah terbebas dari polusi asap akibat pembakaran kayu bakar pada dapur mereka, karena kebutuhan energinya ganti biogas yang lebih praktis dan murah.

Hanya saja tidak semua masyarakat senang dan antusias menggunakan biogas untuk keperluan memasak mereka, termasuk di Dusun Krajan Desa Kemiri, Kecamatan Jabung, Kabupaten Malang. Mereka ini masih beranggapan energi biogas yang dari kotoran sapi tidak layak untuk keperluan memasak. Mereka enggan mengkonsumsi makanan atau minuman yang dimasak menggunakan biogas karena dianggap berbau kotoran. Meskipun jumlahnya tidak banyak inilah tantangan yang harus dihadapi.

Karena itulah perlu sekali dilakukan pemahaman secara terus menerus kepada masyarakat luas bahwa menggunakan energi biogas untuk keperluan memasak adalah aman dan sehat. Hasil olahan masakan dan minuman yang menggunakan biogas sebagai bahan bakar adalah aman, sehat dan halal untuk dimakan. Biogas tidak berbau dan memasak dengan menggunakan biogas hasilnya jauh lebih cepat, lebih baik dari pada menggunakan elpiji ataupun kompor minyak atau kayu bakar. Sangat murah dan praktis.

Untuk dapat memperoleh biogas, para peternak sapi perah harus memiliki "tabung digester" yaitu suatu tempat kedap udara yang menampung kotoran sapi perah mereka. Untuk ukuran rumah 
tangga dengan 3 sampai 10 ekor sapi cukup dibuat tangki digester dengan volume 6 hingga $10 \mathrm{~m} 3$. Proses terjadinya biogas terjadi dalam ruang tertutup yang tanpa oksigen.

Secara sederhana dapat digambarkan bahwa kotoran sapi yang bercampur dengan air seni dan air tanah dikumpulkan dan diaduk sampai lumer dengan alat-alat sederhana seperti sorokan kayu, pengait dari kayu dan besi untuk memisahkan serat-serat dan rumput/ jerami yang tercampur dalam kotoran sapi. Dengan perbandingan $1: 1$ kotoran sapi dan air yang telah lumer dan bebas serat tadi dimasukkan ke dalam Tangki Digester. Hal itu terus dilakukan sambil membersihkan kandang baik di pagi hari ataupun di sore hari. Selanjutnya dalam Tangki digester akan terjadi proses pembusukan yang terdiri dari dua tahap, yaitu proses aerobik dan proses anaerobik. Pada proses yang pertama diperlukan oksigen dan hasil prosesnya berupa karbon dioksida (CO2). Proses ini berakhir setelah oksigen didalam alat ini habis. Selanjutnya proses pembusukan berlanjut pada tahap kedua (proses anaerobik). Pada proses yang kedua inilah biogas dihasilkan. Dengan demikian, untuk menjamin terjadinya biogas alat ini harus tertutup rapat, tidak berhubungan dengan udara luar sehingga tercipta kondisi hampa udara.

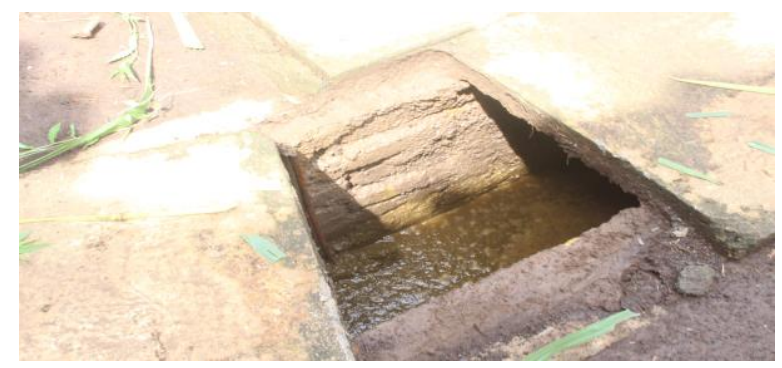

\section{Gambar 1. Bentuk jadi tabung biogas dan tempat slurry biogas}

Pengisian Tangki digester dilakukan sampai kondisi tangki digester telah penuh berisi campuran air dan kotoran sapi. Dalam kurun waktu seminggu setelah isian tangki digester penuh energi biogas akan terkumpul dan siap untuk digunakan untuk memasak. Biogas yang tersalurkan ke dalam jaringan pipa air 0.5 dim dan terhubung ke dapur dan disalurkan kedalam kompor biogas siap untuk digunakan dengan membuka stop kran dan menyulut kompor biogas dengan korek api biasa. Bila energy biogas tidak digunakan, maka secara otomatis energi yang ada dalam tangki digester akan mendorong kotoran sapi keluar di lubang pembuangan biogas yang telah dibuat dan disalurkan kedalam kolam-kolam penampungan pembuangan limbah biogas.

Limbah biogas yang keluar melalui saluran pembuangan ini sudah tidak mengandung gas metan, kalaupun ada jumlahnya sudah menurun jauh dibandingkan sebelum terbentuk biogas. Limbah biogas ini kaya akan zat-zat hara yang berguna untuk kesuburan tanah dan cocok digunakan sebagai pupuk organik.

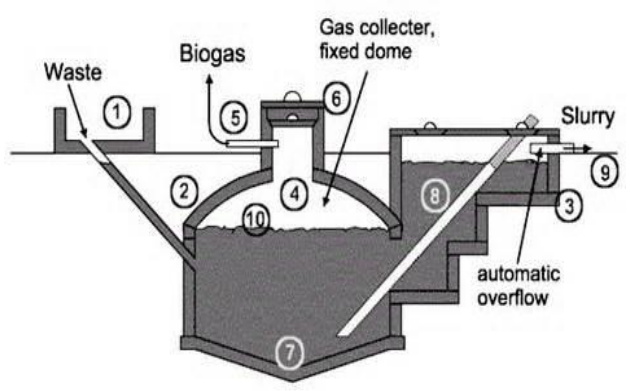

Gambar 2. Contoh Penampang Konstruksi Pembuatan Biogas 
B. Proses Pembuatan Kontruksi Biogas di Rumah Bapak Marno dan Bapak Riyanto.

Untuk pembuatan Tabung Digester, sebagai tempat penampungan kotoran sapi yang akan diproses menjadi biogas yang perlu dilakukan pertama kali adalah membuat lubang galian sedalam dan selebar sesuai kebutuhan tangki digester yang akan dibuat. Untuk ukuran rumah tangga dengan jumlah sapi 3 sampai 10 ekor maka volume tangki digester antara 6 hingga $10 \mathrm{~m} 3$. Rata-rata seekor sapi menghasilkan volume $2 \mathrm{~m} 3$ biogas. Bila Tabung digester lebih besar dari ketentuan jumlah peliharaan sapinya maka akan terjadi kekurangan jumlah kotoran sapi sebagai bahan baku pembuatan biogas. Sebagai akibatnya tekanan biogas untuk memasak akan berkurang sehingga kompor biogas tidak akan menyala. Bila sebaliknya yaitu jumlah sapinya lebih banyak dari ketentuan tsb di atas, maka kotoran sapinya berlebihan dan tidak dapat dimasukkan ke dalam tangki digester.

Untuk peternak sapi bapak Marno dan bapak Riyanto dengan jumlah 6 ekor sapi perah saat pembuatan biogas dikerjakan, dibuatkan lubang digester kapasitas $6 \mathrm{~m} 3$. Setelah lubang dibuat melingkar seperti membuat sumur, kemudian dibuatkan lubang persegi disebelahnya untuk lubang pembuangan setelah proses biogas terbentuk.

Pengerjaan selanjutnya adalah melakukan pemasangan batu merah dan pengerjaaan kerangka besi untuk dasar pembuatan kubah digester. Selanjutnya dilakukan pemasangan kayu papan untuk pengerjaan begesting yang dilakukan sekeliling sumur. Dilakukan pengecoran semen, pasir dan batu koral dengan perbandingan 1:1. Langkah berikutnya pembuatan kerangka kubah dari besi cor, pemasangan triplek dan kayu untuk membentuk dan menahan isian cor beton kubah. Dilakukan penghalusan pada seluruh pasangan batu bata merah dan cor beton yang dibuat agar tidak terjadi kebocoran. Dan terakhir dilakukan pengecatan pada bagian dalam digester dengan cat vitex acrilik agar kuman/ bakteri terbentuknya biogas dapat hidup dan berkembang.

Ketika Lubang Pemasukan, Lubang digester dan Lubang pengeluaran limbah telah dikerjakan dan tinggal menunggu kering, sambil menunggu Instalasi pipa Biogas dirangkai dan dibuat sampai ke dapur dan kompor biogas. Untuk memudahkan pemasukan kotoran sapi bercampur air seni dan air ke dalam tabung digester yang telah di buat, Dibuat pula saluran permanen dari beton cor dan pipa permanen ukuran $3 \mathrm{dim}$ di belakang kandang bapak Marno dan Riyanto sepanjang kurang lebih 9 meter. Saluran ini akan memudahkan kotoran sapi dari kandang langsung masuk kedalam lubang (in let) pemasukan sebelum masuk ke dalam digester.

Setelah dilakukan pengisian Tangki digester dengan kotoran sapi secara terus menerus sampai tangki digester penuh, kurang lebih seminggu kemudian biogas telah terbentuk dan hasilnya sungguh luar biasa. Tekanan biogas demikian kuat, sehingga kompor biogas di dapur bapak Marno dan Riyanto langsung bisa dinyalakan. Kualitas api yang dihasilkan pada awalnya masih berwarna kuning marun tetapi dalam selang waktu 2 hari kemudian api sudah jauh lebih biru dan tekanannya lebih baik dari pada menggunakan elpiji $3 \mathrm{Kg}$.

Pengerjaan Biogas di rumah bapak marno dan riyanto telah selesai dan sukses sampai menyala di dapur rumah. Sampai dengan laporan ini dibuat, Kualitas Biogas dan Instalasinya di rumah bapak Marno dan Riyanto masih dalam pengawasan konsultan biogas dan tim IbM IKIP Budi Utomo Malang, tindakan pengawasan dilakukan untuk menjaga kemungkinan ada kebocoran dan bagaimana teknis perawatan yang harus dilakukan. 
C. Penyuluhan Kesehatan dan

Kebersihan Lingkungan.

Melanjutkan kegiatan pengabdian di dusun Krajan desa Kemiri, Kecamatan Jabung, Kabupaten Malang adalah bertemu dengan masyarakat desa terutama keluarga yang menjadi sasaran dalam kegiatan pengabdian ini. Tanggapan mereka sangat antusias dan mengharapkan kegiatan pengabdian masyarakat serupa dilakukan secara berkelanjutan di lingkungan desa mereka. Mereka sangat ingin kegiatan ini dilakukan secara rutin tiap tahun dengan sasaran yang berbeda dan jenis pengabdian masyarakat yang berbeda sesuai dengan permasalahan yang mereka hadapi sehari-hari berdasarkan skala prioritas tingkat urgensi kebutuhan yang paling mendasar bagi kehidupan mereka.

kegiatan penyuluhan tentang pentingnya kesehatan dan kebersihan sanitasi lingkungan serta pemanfaatan kotoran sapi sebagai bahan pembuatan biogas terutama pemeliharaan tabung biogas yang sudah ada. Kebersihan lingkungan dan permasalahan sanitasi lingkungan di pedesaan menjadi problem baru bagi masyarakat pedesaan seiring dengan semakin bertambahnya jumlah penduduk di pedesaan. Dengan bertambahnya jumlah penduduk di pedesaan, maka lingkungan pemukiman penduduk pedesaan yang dulunya antara rumah yang satu dengan rumah yang lain terdapat ruang terbuka yang sangat lapang yang biasanya berupa kebon atau sawah atau tanah lapang menjadi semakin berkurang, bahkan di beberapa tempat dilingkungan dusun Krajan, desa Kemiri sudah seperti pemukiman di kota yang padat penduduk. Konsentrasi pemukiman penduduk yang berkumpul di satu tempat tentunya memerlukan penataan lingkungan yang bersih dan sehat.

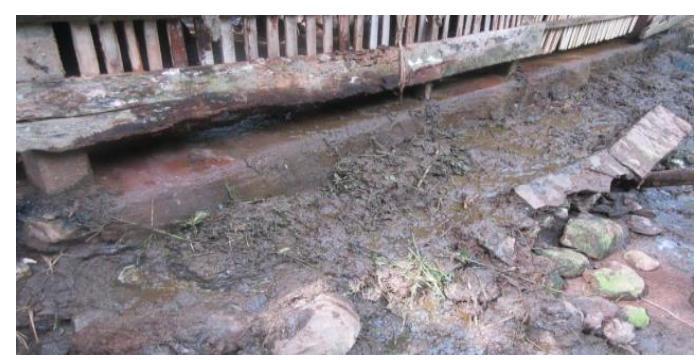

\section{Gambar 3. Suasana sanitasi lingkungan sekitar sebelum ada IBM}

Untuk penyuluhan kebersihan dan kesehatan sanitasi lingkungan diharapkan kesadarannya untuk menjaga kebersihan lingkungan. Lingkungan yang bersih membuat lingkungan sehat, lingkungan yang sehat akan membuat masyarakat yang tinggal di tempat tersebut akan terjaga pula kesehatannya. Apabila Lingkungan tidak dipelihara dengan baik akan menjadi kotor dan tidak sehat. Lingkungan yang tidak sehat akan mendatangkan penyakit, sehingga masyarakat yang bermukim di daerah tersebut akan rentan untuk terserang penyakit.
Kebersihan kandang ternak, utamanya ternak sapi harus selalu bersih. Harus selalu tersedia air dan sorokan (alat) untuk membersihkan kotoran sapi. Sapi perah penghasil susu sapi, kotorannya basah dan air seni sapi jumlahnya banyak, karena itu harus rajin dibersihkan. Bila kandang ternak sapi bersih maka ternak sapipun menjadi sehat, ternak sapi perah yang sehat produksi susunya akan banyak. Bila sebaliknya maka ternak sapi perah akan mudah terserang berbagai penyakit, dan berakibat produksi susu sapi menurun. 


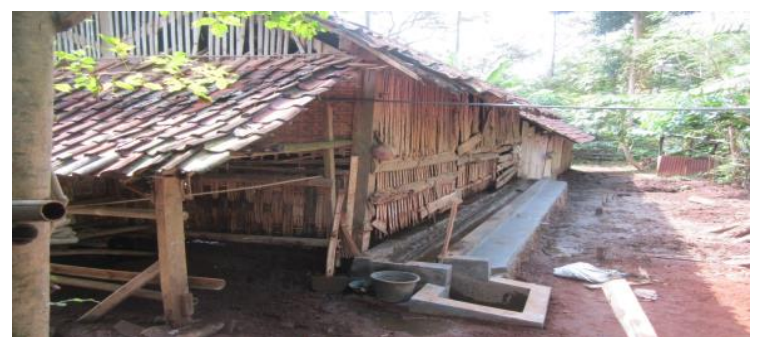

Gambar 4. Saluran Sanitasi setelah mendapatkan IBM

Demikian pula lingkungan kandang juga harus bersih, kotoran sapi dan air seninya harus dibuang di tempat yang disediakan. Sisa-sisa pakan ternak yang tidak terpakai atau sudah terbuang di sendirikan dan dibuang di tempat terpisah. Selalu mengawasi tempat pembuangan kotoran sapinya setiap hari, agar kotoran sapi tidak meluber ke jalan, sungai dan tetangga terdekat. Bila bau kotoran sapi terasa sangat menyengat dan bisa menggangu tetangga kiri dan kanan, Para peternak sapi perah diminta member obat-obatan pro biotik yang dapat mengurai bau kotoran sehingga tidak lagi berbau dan menggangu lingkungan. Hal itu dilakukan setiap hari, di musim kemarau apalagi di musim penghujan.

Kotoran sapi yang dibiarkan menumpuk dan tidak segera dibersihkan akan membahayakan kesehatan manusia dan hewan ternak itu sendiri. Karena itu para peternak sapi perah harus rajin dan senang untuk selalu membersihkan kotoran sapi dan menjaga kebersihan kandang ternak sapi mereka beserta lingkungannya.

\section{Pembuatan Pupuk Organik Limbah Biogas}

Pengerjaan Biogas di rumah bapak Marno dan Riyanto telah selesai dan sukses sampai menyala di dapur rumah. Hingga sekarang kualitas biogas dan Instalasinya di rumah bapak Marno dan riyanto masih dalam pengawasan. Selanjutnya Tim IbM IKIP Budi Utomo Malang menjalankan program selanjutnya yaitu pengelolaaan limbah biogas dari kedua tempat penampungan tersebut.

Langkah tersebut sudah selesai dikerjakan melalui pengolahan sisa-sisa limbah kotoran sapi yang keluar dari dome biogas yang sudah terisi penuh dan keluar melalui salauran pembuangan. Dikarenakan rentangan waktu pembuatan dan penggunaan masih tergolong baru dan pendek, sehingga saat ini masih belum keluar banyak dari tempat dome biogas dan masih digunakan sebagai bahan biogas rumah tangga.

Pemberdayaan masyarakat sasaran IBM ini digunakan untuk mengolah dan memanfatkan sisa-sisa limbah biogas yang ada di sekitar rumah masyarakat setempat. Iharapkan dengan pemanfaatan limbah biogas dan limbah kotoran ternak dari lingkungan sekitar dapat memberikan keuntungan yang ekonomis dalam meningkatkan pendapatan bagi keluarga sasaran IBM.

Proses pemberdayaan masyarakat sasaran IBM ini dilakukan selama kurang lebih 2 bulan dengan memanfaatkan fasilitas desa baik itu saluran pengairan dari desa dan lahan kosong yang berada di ujung desa yang belum dimanfaatkan. Pemafaatan limbah biogas ini juga membutuhkan waktu yang cukup lama, hal ini dikarenakan menunggu cuaca yang panas yangnantinya digunakan untuk mengeringkan hasil olahan limbah tersebut.

Proses pertama yang dilakukan dalam mengolah limbah biogas menjadi pupuk organic kering, yaitu dengan mengumpulkan sisa-sisa biogas yang keluar dari 2 tabung biogas digester hasil IBM ini. Sedikitnya ada 20 kilogram 
limbah biogas basah yang dapat dikumpulkan dari 2 tabung biogas digester tersebut. Kemudian langkah berikutnya dengan menampungnya di dalam satu wadah besar lubang (joglangan) untuk dicampur dengan bahan lainnya yaitu grajen kayu yang mudah didapat di sekitar desa Kemiri, Kecamatan Jabung, Kabupaten Malang. Untuk ukuran atau takaran dalam mengolah limbah biogas cair itu didapatkan perbandingan 1:1 antara biogas cair dengan grajen kayu.

Setelah dilakukan pengolahan limbah biogas cair dengan bahan campurannya didapatkan olahan basah yang sudah tercampur rata. Kemudian untuk menjadikan pupuk organic dilakukan pengendapat bahan pupuk organic kurang lebih 10 hari tergantung dengan cuaca saat itu. Setelah olahan diendapkan dan kemudian dkeringkan maka bahan pupuk tersebut sudah dalam kondisi kering dan padat.

Proses kedua yangdilakukan adalah dengan mengolah-alik bahan pupuk organic itu untuk mengetahui kelembapan dan hasil pengendapatan tersebut. Agar menjadi pupuk organic yang siap digunakan, maka dilakukan pengayaan pupuk biogas hasil pengendapan tersebut. Fungsi dilakukan pengayakan itu ditujukan untuk memisahkan bahan pupuk organic dari sampah dan menghancurkan pupuk menjadi lebih halus. Sambil melakukan pengayaan dengan alat sederhana juga dilakukan pengolak-alikan dengan cangkul kayu agar lebih cepat mongering dan terpencar halus.

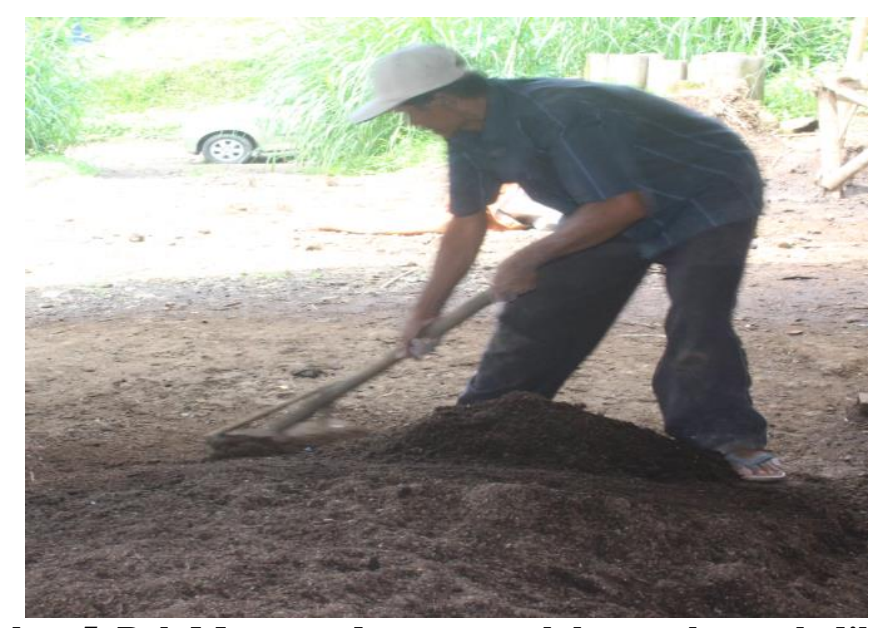

\section{Gambar 5. Pak Marno sedang mengolah pupuk untuk dikemas}

Bahan pupuk organik hasil biogas tersebut ketika sudah melalui pengayaan siap untuk dikemas sesuai dengan keinginan konsumen. Biasanya dikemas dengan ukuran 5 kilogram. Pengemasanya pun juga sederhana hanya membutuhkan plastik dan pengerat untuk menutup kemasan.

Namun dalam program kegiatan pengolahan limbah biogas ternak sapi perah ini, tujuan utama adalah melatih masyarakat sasaran IbM untuk dapat mengolah hasil dari sisa-sisa biogas untuk dijadikan pupuk organic kering yang mempunyai tingkat ekonomis bagi mereka. Diharapakan kegiatan ini dapat terus dikembangkan pada tahun yang akan datang, mengingat bahan pembuatannya yang relatif murah dan melimpah.

\section{KESIMPULAN}

Adapun kesimpulan yang dapat ditarik dari pelaksanaan pengabdian tersebut antara lain:

A. Limbah Kotoran sapi yang membuat lingkungan tercemar dapat dimanfaatkan menjadi sesuatu yang 
berharga bagi lingkungan tempat kotoran sapi tersebut berasal.

B. Manfaat limbah kotoran sapi dapat digunakan sebagai bahan pembuatan Biogas sebagai sumber energi alternatif pengganti bahan bakar minyak dan gas elpiji serta pengganti kayu bakar.

C. Teknik pembuatan biogas sangat sederhana dan mudah dipelajari oleh masyarakat awam di pedesaan sekalipun.

D. Disamping menghasilkan biogas, dihasilkan juga limbah biogas berupa bioslurry yang dapat digunakan sebagai pupuk organik kering.

E. Program IbM IKIP Budi utomo di Dusun Krajan Desa Kemiri Kecamatan Jabung, Kabupaten Malang sangat bermanfaat bagi Mitra IbM karena dapat memecahkan masalah kebersihan dan kesehatan lingkungan juga sekaligus memperoleh energi biogas yang sangat berarti dalam memenuhi kebutuhan energi serta pupuk organik.

Selain kesimpulan yang diberikan pada pengabdian ini, peneliti juga memberikan saran untuk dapat dilaksanakan dikemudian hari, antara lain:

A. Kapasitas volume tangki digester sebagai tempat prosesor pembuatan biogas hendaknya disesuaikan dengan jumlah kapasitas kotoran sapi yang dihasilkan oleh peternak sapi yang akan membuat biogas. Bila terlalu besar akan terjadi kekurangan bahan baku (kotoran sapi) dalam proses pembuatan biogas. Sebaliknya bila terlalu kecil, kotoran sapi akan berlebih dan tidak tertampung.

B. Model Tangki Digester dicarikan yang mudah perawatannya.

C. Program Pembuatan Tangki Digester biogas tersebut dianjurkan bisa dilanjutkan, pertimbangan daerah Dusun Krajan, Desa Kemiri, Kecamantan Jabung, Kabupaten Malang ini sebagian besar adalah peternak sapi perah, dan belum semua rumah warga mempunyai Tangki Disaster sendiri, sehingga belum maksimal kegunaan limbah kotoran sapi di Dusun tersebut.

D. Mitra IbM juga harus menguasai teknis perawatan tabung biogasnya, sehingga kelangsungan pembuatan biogas dapat lestari.

E. Diperlukan pemahaman yang terus menerus kepada masyarakat di lingkungan para peternak sapi perah agar mereka mau memanfaatkan kotoran sapi untuk biogas sebagai pengganti energi alternatif, agar masyarakat terbiasa memasak makanan mereka dengan biogas dan tidak merasa jijik lagi.

F. Diperlukan program lanjutan yang mendukung pemberdayaan masyarakat desa dalam pemanfaatkan limbah biogas sapi ternak untuk meningkatkan tingkat ekonomis berupa produk olahan pupuk organic kering.

\section{REFERENSI}

Rochmat Purboyo dan Siti Nuraisyah Dewi, “ TEKNOLOGI BIOGAS: Pacu produksi

pertanian"(http://en.bisnis.com/articles/t eknologi-biogas-pacu-produksi-

pertanian) diakses tanggal 10 Maret 2015.

http://www.alpensteel.com/article/67-

107-energi-bio-gas/263--teknologi-

pembuatan-biogas-secara-

sederhana.html diakses tanggal 10

Maret 2015.

http://manglayang.blogsome.com/biogasinfrastruktur-part1/ diakses tanggal 11 Maret 2015.

http://energipersada.wordpress.com/tag/b iogas/) diakses tanggal 17 Maret 2015. 
http://www.scribd.com/doc/17020876/PE

MBUATAN-BIOGAS diakses

tanggal 17 Maret 2015.

www.anneahira.com/manfaat-pupuk.htm diakses tanggal 4 Maret 2015.

http://id.wikipedia.org/wiki/Pupuk_Orga nik diakses tanggal 4 Maret 2015.

http://www.petrokimiagresik.com/Pupuk/ Urea.ZA), diakses tanggal 4 Maret 2015.

http://www.antarabengkulu.com/berita/2

1976/presiden-luncurkan-buku-

proyeksi-penduduk-2035 diakses

tanggal 4 Maret 2015. 